\title{
KATARZYNA KUCZYŃSKA-KOSCHANY
}

\section{Gest pośmiertnego pisania i inne ,gesta” poetyckie (Verlaine, Rimbaud)}

Przyjaźń to małżeństwo dwóch osób, które ze sobą nie sypiają. Jules Renard ${ }^{\mathrm{x}}$

Kocham Cię i chcę z Tobą spać - taka zwięzłość w przyjaźni nie jest dana.

Cwietajewa w liście do Rilkego

Tyś mnie bowiem pokochał tak, jak było trzeba.

Verlaine do Rimbauda ${ }^{2}$

\section{Przyjaźń czy kochanie?}

Paul Verlaine i Arthur Rimbaud. Rainer Maria Rilke i Marina Cwietajewa ${ }^{3}$. Andrzej Czajkowski i Anita Janowska ${ }^{4}$.

Czy przyjaźń może się rozpocząć olśnieniem i zaćmieniem? Czy może trwać, gdy grozi jej miłość? Przypadek Verlaine’a

I To zdanie J. Renarda przytoczył K. Brandys w szkicu o Ulicy Vaneau. Zob. K. Brandys, Charaktery i pisma, Londyn 1991, s. 47.

${ }^{2}$ Jest to motto biografii, której autorem jest F. d'Eaubonne, Niepokój. Życie Pawła Verlaine'a, przeł. J. Dackiewicz, Warszawa 1963. Tytuły poszczególnych części tej biografii wskazują wyraźnie na cezury Rimbaudowskie w życiu Verlaine'a: Zanim nadszedt...; Gdy nadszedt...; Gdy odszedt... W dalszych przywołaniach używam skrótu $\mathrm{N}$ z numerem strony.

3 M. Cwietajewa, B. Pasternak, R.M. Rilke, Listy (1926), przeł. J. Juryś, A. Mietkowski, A. Zagajewski, „Zeszyty Literackie” 1986, nr 14, s. 63-109; zob. J. Zieliński, Listy troiste, „Zeszyty Literackie” 1986, nr 14, s. 57-62; B. Pasternak, List żelazny, w: Drogi napowietrzne i inne utwory, przeł. S. Pollak, Warszawa 1973, s. 375-535.

4 „....mój diabet stróż”. Listy Andrzeja Czajkowskiego i Haliny Sander [Anity Janowskiej], wybór, oprac. A. Janowska, Warszawa 1988. Dalej posługuję się skrótem MDS z numerem strony. 
i Rimbauda daje na pierwszy rzut oka odpowiedź przeczącą. W nie-relacji (Un-beziebung 5 ) Cwietajewej i Rilkego rzecz wydaje się jeszcze bardziej skomplikowana, okazuje się nieustannym balansowaniem w przestrzeni nie do końca nazwanego. Czajkowski i Janowska potrafią przyjaźnić się w listach (wzorem Franza Kafki czy Brunona Schulza i ich narzeczonych), gdy się jednak - nie daj Bóg - zobaczą, zaraz w głowie im łóżko, dziecko (Gaspard albo Daniel, kłócą się o imię), wszystko.

Wybrałam trzy pary przyjaciół-kochanków, by pokazać nieostrość kategorii przyjaźni, gdy ta znajdzie się w miłosnych, albo tylko erotycznych, tarapatach. Dominować będą rozważania o (paradygmatycznej niejako dla kulturowo tabuizowanej przyjaźni) homoerotycznej relacji Verlaine - Rimbaud: młodszość uwodzi tu starszość, chłopiec - mężczyznę, apostata - rozpaczliwie i do końca życia wahającego się, człowiek wolny - ojca rodziny. Relacje poety i poetki (Rilke - Cwietajewa) - rozdzielonych odległością, kulturą - czy pianisty o skłonnościach biseksualnych i psycholożki, bardzo heteroerotycznej, wciąż popełniającej jakieś nieudane małżeństwa (Czajkowski - Janowska) nie mają jednak takiego potencjału transgresywnego. Austriakowi i Rosjance trzeba by poświęcić więcej uwagi, zatem rezygnuję całkowicie $\mathrm{z}$ rozważań, które być może ułożą się w osobny tekst. Parze polskich twórców przyjrzę się chętniej, ponieważ to nader barwna niteczka w polskiej recepcji Rimbauda, recepcji, którą również zajmuję się w niniejszej próbie.

Interesuje mnie właśnie ów moment graniczny, stan nieodróżnialności. Emocje w stadium transgresji. Chciałabym zajrzeć przez teksty literackie i listy tam, gdzie zażyła znajomość przekracza mocną tożsamość (przede wszystkim seksualną), gdzie sama nie wie, czym jest, a pomimo to (czy może dzięki temu) nie przestaje być relacją. Każdy psycholog powiedziałby toksyczną; każdy badacz literatury - twórczą.

Zajmować mnie będzie także to, co nazywam gestem pośmiertnego pisania. Gestem pojmowanym jako akt quasi- erotyczny, a także akt $\mathrm{w}$ sensie etymologicznym (powiedzmy - „gesta” - gatunek przeniesiony eseistyczną dezynwolturą na relacje prywatne).

5 Określenie T. Topolanek. Zob. T. Topolanek, Rainer Maria Rilke - Marina Cvetaeva: eine „Un-Beziehung”?, Salzburg 1995. Podobnie można by myśleć o relacji I. Bachmann i P. Celana. Na ten temat zob. K. Kuczyńska-Koschany, Wieczór pijany i inne (niedo)statki [referat zaprezentowany na seminarium Konstelacje Ingeborg Bachmann, Poznań, 27 maja 2009, zgłoszony do druku w tomie Wieczór pijany i inne (niedo)statki, red. Ł. Musiał, J. Roszak]. 
Verlaine wydaje po Rimbauda śmierci-dla-poezji, w roku 1886, Poetów przeklętych, i to - jak pisze o dawnym kochanku, któremu zawdzięcza (bez cudzysłowu) szał, więzienie, powrót do katolicyzmu, dożywotnią utratę żony i syna - daje do myślenia $^{6}$. Cwietajewa posyła namiętne listy do umarłego Ril$\mathrm{kego}^{7}$. Janowska, ukrywając swoją tożsamość pod pseudonimem Halina Sander, opatruje wstępem własną korespondencję z Czajkowskim, ale zdradza ją to, że i w przedsłowiu, i w przypisach ciągle pisze „Andrzej”, a także fakt, iż wycina fragmenty najbardziej intymne (czy ktoś obcy miałby prawo do takiej cenzury?). Po latach zresztą ujawnia tamte zabiegi w wywiadzie ${ }^{8}$.

Gest pośmiertnego pisania wydaje mi się charakterystyczny - chociaż nie jest jedynym możliwym gestem - dla przyjaźni zaplątanej w okoliczności miłosne. Ten gest wykonuje zawsze osobnik mocniej uwikłany uczuciowo, ten, który „kocha bardziej”, jak powiedziałby Wystan H. Auden: Verlaine, gdy Rimbaud już kocha tylko Afrykę i złoto (i Abisynkę Mariam", zgodnie ze swą cudowną, biseksualną uczciwością); Cwietajewa, gdy Rilkego już nie ma (ale przecież przed chwilą był); Janowska, gdy jest już starą kobietą, której ciąży niewypowiedziane.

Potem można już zapić się na śmierć, mylić kochanki, popełniać samobójstwo, odchodzić. Gest pośmiertnego pisania zaświadcza jednak - co najmniej - o przyjaźni/miłości nieodróżnialnej. Scripta manent.

${ }^{6}$ W roku 1934 ukazały się nakładem „Mercure de France” zebrane w jednym tomie wszystkie artykuły i wiersze Verlaine'a o Rimbaudzie. Zob. Verlaine o Rimbaudzie, „Wiadomości Literackie” 1934, nr 40, s. 2: Kronika francuska. Pismo to regularnie informowało o różnych istotnych kwestiach dotyczących Rimbauda i pośmiertnych losów jego dzieł. W związku z wątkiem tu poruszanym warto odnotować streszczenie wywiadu udzielonego przez wdowę po Verlainie F. Harrisowi, Verlaine i Rimbaud, „Wiadomości Literackie” 1925, nr 34, s. 3: Notatki.

7 List do Rimbauda (zmarłego 10 listopada 1891 r. w Marsylii) wysyła, ignorując jego śmierć, także G. Nouveau -12 grudnia 1893 r. Ponieważ w prasie paryskiej ukazał się nekrolog Rimbauda, gest wydaje się zamierzony. Jest właśnie gestem pośmiertnego pisania. Zob. A. Rimbaud, Oeuvres complètes, wyd. A. Guyaux, współpr. A. Cervoni, Paris 2009, s. 804-805. Dalej stosuję skrót OC z numerem strony.

${ }^{8}$ Mój diabet stróż [z Anitą Janowską rozmawiał Dariusz Zaborek], „Duży Format” [dodatek], „Gazeta Wyborcza”, 3 maja 2010.

9 Fotograficzną podobiznę tej pięknej dziewczyny, abisyńskiej chrześcijanki, która żyła z Rimbaudem w latach 1882-1886, opublikowano w „Le Magazine Littéraire”. Zob. V. Marin La Meslée, „Artbur Rimbaud, inédits d'Aden, „Le Magazine Littéraire”, czerwiec 2010, s. 9. Pojawia się ona także na okładce właśnie wydanej we Francji książki: A. Bardey, Barr-Adjam, souvenirs du patron de Rimbaud. Aden-Harar 1880-1887, wstęp J. Tubiana, przedmowa C. Jeancolas, Paris 2010. 


\section{2. „Crimen amoris”: Verlaine i Rimbaud}

Verlaine rozpoczął prezentację Rimbauda jako poety przeklętego tak:

Nous avons eu la joie de connaître Arthur Rimbaud. Aujourd'hui des choses nous séparent de lui sans que, bien entendu, notre très profonde admiration ait jamais manqué à son génie et à son caractère ${ }^{\mathrm{IO}}$.

Mówił wprost o „stosunkowo odległej epoce naszej zażyłości [przyjaźni]" („l'époque relativement lointaine de notre intimité”; LPM, 21), dał także opis Rimbauda, który można by nazwać lapidarnym ćwiczeniem z zachwytu:

L'homme était grand, bien bâti, presque athlétique, au visage parfaitement ovale d'ange en exil, avec des cheveux châtain-clair mal en ordre et des yeux d'un bleu pâle inquiétant ${ }^{\mathrm{II}}$. (LPM, 21)

Tak pisze kochanek, który stracił wszystko: żonę („gęś”, jak o Matyldzie powiada Jerzy Lisowski ${ }^{\mathrm{I}}$ ), syna (urodzonego - jak nie wierzyć w samostwarzający się mit biograficzny tego samego dnia, co Rimbaud ${ }^{\mathrm{I}}$, i to $\mathrm{w}$ roku, gdy poeci się po-

ro P. Verlaine, Les poètes maudits, Paris 1920, s. 21: „Cieszyliśmy się znajomością Artura Rimbauda. Dziś pewne rzeczy oddzielają nas od niego, chociaż, co zrozumiałe, nasz najgłębszy podziw nie uchybił nigdy jego geniuszowi i charakterowi”. Dalej stosuję skrót LPM z numerem strony; jeśli nie zaznaczono inaczej - przeł. K.K.K.

II „Mężczyzna to był wielki, dobrze zbudowany, prawie atletyczny, o doskonale owalnej twarzy wygnanego anioła, jasny szatyn, o włosach w nieładzie i niepokojąco bladobłękitnych oczach".

I2 J. Lisowski tworzył jedyne w swoim rodzaju makrobiogramy (mikroeseje) biograficzne i opatrywał nimi, zamiast konwencjonalnymi notami, swe prezentacje poetów francuskich. Doprowadził ten quasi-gatunek do doskonałości. Na temat Verlaine’a pisał m.in.: „W roku 1870 żeni się z gęsią. Podejrzany o sympatie dla komunardów, nie bez kozery zresztą, opuszcza na pewien czas Paryż i młodą żonę, którą niebawem (1872) porzuci dla młodego Rimbauda. Podróżuje z nim do Anglii, przebywa w Brukseli, tam oddaje do niego dwa strzały, gdy Rimbaud postanawia odejść" (Od Chateaubrianda do Germaina Nouveau, w: Antologia poezji francuskiej, t. 3, Warszawa 2000, s. 643). Lisowski odmawia M. Mauté de Fleurville nazwiska, a nawet imienia, jest „gęsią”, po prostu. Rimbaud jest za to jeden jedyny, nie trzeba dodawać żadnych wyróżników. Taki subiektywny biogram koresponduje z mitem biograficznym tego poety jako geniusza uniwersalnego.

I3 Być może jest to rzeczywiście wersja już zmityzowana. A. Drzewicka podaje inną datę narodzin syna poety (o imieniu Georges): nie 20 października 1871 r., ale 30 października 1871 r. Zob. P. Verlaine, Wybór poezji, oprac. A. Drzewicka, Wrocław 1980, s. X. Dalej stosuję skrót BN II 200 z numerem strony. 
znali $^{\text {4}}$ : 1871), głowę, wiarę (przejściowo tylko odzyskaną). Zostały mu absynt i zachwyt, przypominanie twarzy „doskonale owalnej wygnanego anioła”, włosów w nieładzie i „niepokojąco bladobłękitnych oczu".

W przyjaźni, którą chyba lepiej nazywać zażyłością, wykorzystując dwuznaczność francuskiej intimité, było, z punktu widzenia Verlaine'a, kilka momentów dramatycznych: olśnienie-zaćmienie (świetnie pokazane w filmie Agnieszki Holland), a potem odkrycie, że kocha się osobę, nie płeć (stąd nieustanne wahanie pomiędzy Matyldą - „małą wróżką” vel „gęsią” a Rimbem); Bruksela; Stuttgart; wreszcie dwie wiadomości o śmierci Rimbauda: najpierw pogłoska, potem nekrolog.

Był też jeden dominujący w przyjaźni-zauroczeniu komponent: Synczyzna, czyli przedrzeźnianie kulturowej zasady starszeństwa - tu młodszy dyktował warunki, zarówno poetyckie, jak i dotyczące współżycia (w każdym ze znaczeń tego słowa). Podkreślają to zgodnie wszyscy znani mi biografowie i monografiści zarówno Verlaine'a, jak i Rimbauda (pierwsi najczęściej z ubolewaniem, drudzy zazwyczaj z entuzjazmem). To Rimbaud decydował o swoim losie, zawsze sam, i o losie Verlaine'a, póki byli razem; wspomnienie genialnego młokosa prześladowało starszego poetę do końca życia, podczas gdy Rimbaud po katharsis Sezonu w piekle zdaje się Verlaine'a nie znać, nigdy go już nie wspomina. Także w poezji Rimbaud był forpocztą: Rimbaud-ikonoklasta, mówi o nim Octave $\mathrm{Nadal}^{\mathrm{I}}$, prekursor wiersza wolnego (i wielu innych wolności). Verlaine, pozostał według określenia Nadala ${ }^{16}$ - ortodoksyjny, nigdy nie stosował konsekwentnie vers libre, co najwyżej akcydentalnie uwalniał niektóre wersy ze swoich wierszy ${ }^{17}$ (nigdy też nie przyznał sobie innej wolności bez ograniczeń).

${ }^{{ }^{4} 4} \mathrm{Z}$ tej okazji J. Renard zanotował w swym dzienniku 14 marca 1892 r.: „Est-que le fils de Verlaine ressemble à Rimbaud?” (polski przekład J. Guze: „Czy syn Verlaine'a podobny jest do Rimbauda?”). J. Renard, Journal 1887-1910, oprac. L. Guichard, G. Sigaux, wstęp, zestawienie chronologiczne i indeks G. Sigaux, Paris 1960, s. 120 (dalej skrót J z numerem strony); idem, Dziennik, wybór, przeł., oprac. J. Guze, Warszawa 1993 (dalej skrót D z numerem strony).

${ }_{5}$ O. Nadal, Paul Verlaine, Paris 1961, s. 154.

I6 Ibidem, s. 155.

${ }_{7}$ Por. K. Wojtynek-Musik, Poétiser à la manière symboliste. Étude sur les techniques symbolistes de l'imaginaire et de la versification, Katowice 2000, s. 79, 85 . W rozdziale $\mathrm{V}$ autorka rozpatruje symbolistyczne odmiany wersyfikacyjne: le vers régulier (wersyfikacja regularna), le vers libéré (wersyfikacja uwolniona; tę pokazuje na przykładzie systemu Verlaine’a, wyłożonego w jego Artpoéti$q u e)$, le vers libre (wiersz wolny). Wersyfikacja proponowana przez Verlaine'a była rodzajem pomostu między tradycyjną (regularną) wersyfikacją a całkowicie 
Od wątku olśnienia-zaćmienia rozpoczyna się list-oczekiwanie, napisany (w Paryżu) przez Verlaine'a do Rimbauda na przełomie sierpnia i września $1871 \mathrm{r}$. List jest legendarny, bo właściwie znamy $\mathrm{z}$ niego dziś tylko jedną frazę, i to cytowaną z pamięci przez Ernesta Delahaye'a, w dwóch wersjach: „Venez, chère grande âme, on vous appelle, on vous attend" (OC, 364, wersja z roku $1923^{\mathrm{I} 8}$; OC, 996, wersja z roku $1925^{\mathrm{I} 9}$; „Przybywaj, droga wielka duszo, wzywamy cię, oczekujemy”) albo „Venez, venez vite, chère grande âme... on vous désire, on vous attend!” ${ }^{\circ}$ (OC, 996, wersja z roku 1900; „Przybywaj, przybywaj prędko, droga wielka duszo... (po)żądamy cię, oczekujemy" ${ }^{2 \mathrm{I}}$. Bardziej kategoryczne, nacechowane emocjami (wykrzyknik, czasownik wyrażający żądanie i pożądanie) jest wezwanie drugie - i ono sytuuje się najbliżej rzeczywistych zdarzeń (choć zostało zapisane trzy dekady po nich). Identyczne wersje $\mathrm{z}$ lat 1923 i 1925 - które ponad półwiecze dzieli od listu Verlaine’a brzmią łagodniej, mniej gorączkowo niż fraza zapamiętana w roku 1900. W każdej jednak z wersji, co uwiarygodnia pamięć jako narzędzie rekonstrukcji słów, powtarza się współbrzmienie „âme” - „attend”, rym niecierpliwie oczekującego, oraz apostrofa „droga wielka duszo”. Verlaine bardzo szybko przekonał się, że przybyło do niego również ciało („nie widział nigdy torsu równie potężnego, mlecznobiałego" - N, 89; „To prymitywne piękno, te bary potężne, te oczy fakira" - N, 105) 22 .

Przybył Zanetto, wcielenie bohatera sztuki Passant François Coppée z 1869 r. - młodzieńca śpiącego pod gołym niebem,

nowatorskim wierszem wolnym. Polegała $\mathrm{m}$.in. na stosowaniu miar parzystych obok nieparzystych, osłanianiu pauz metrycznych dzięki użyciu przerzutni, zastępowaniu rymu bogatego bardziej zniuansowanym współbrzmieniem: asonansem, rymem ubogim lub niedokładnym, na liberalizacji tradycyjnych układów rymów końcowych, naprzemiennym stosowaniu wersów o różnym rozmiarze, przekształcaniu wersu we fragment muzyczny dzięki nagromadzeniu aliteracji i powolnej, spokojnej intonacji.

I8 E. Delahaye, Rimbaud. L'artiste et l'être moral, Paris 1923, s. 23.

I9 E. Delahaye, Souvenirs familiers, Paris 1925, s. 159.

${ }^{\circ}$ E. Delahaye, Histoire d'un cerveau français. [Étude sur Arthur Rimbaud], „L'arc-en-ciel”, lipiec 1900, s. 58.

${ }^{2 I}$ W biografii Verlaine'a ten fragment brzmi: „Przybywaj, przybywaj, droga wielka duszo, uwielbiam pana, czekam” (N, 83).

${ }_{22}$ Znów odwołuję się do biografii Verlaine’a: „Wszystko to, co zawiera i zapowiada osłona cielesności, pozory wszystkiego, co ludzkie, a trzymane na uwięzi przez własne przeznaczenie, skupia się w oczach Artura błyszczących dziko: płomień jasnobłękitny niby płomień ponczu. [...] Wobec takich oczu nie zauważa się już nic zgoła, nawet jedwabistego połysku policzków, ust podłużnych, czerwonych, zaciśniętych nieco, jak gdyby ze wstydu, że są tak wydatne i tak dziecinne; nie widzi się furmańskich ramion ani nędznych, na drutach robionych skarpetek" $(\mathrm{N}, 86)$. 
zajmującego niewiele miejsca i pragnącego niewielu rzeczy, jak sam o sobie mówi (zob. OC, 996). Zanetto - tak podpisywał się Rimbaud w pierwszych listach do Verlaine'a ${ }^{23}$. Jak przypuszcza Françoise d'Eaubonne - starszy poeta reaguje na pseudonim żywo: „ten chłopak interesuje się teatralnymi aktualiami, wie, że od siedmiu miesięcy odnosi triumf sztuka Franciszka Coppée, w której młoda debiutantka, panna Sarah Bernardt, kreuje rolę trubadura Zanetta” (N, 79-80). Autorka biografii Verlaine'a próbuje wyobrazić sobie rosnące zaintrygowanie oczekującego: „Ach, wiersze tego Zanetta! Boże miły - rewelacja! Coś tak, jakby odkryło się skarb w załomie starego muru" (N, 81).

Do wątku olśnienia-zaćmienia odwołuje się Ewa Sonnenberg w dwóch tekstach: prozatorskim apokryfie i poetyckiej parafrazie, będącej przepisaniem tekstu o szczególnej relacji między mężczyznami na podobną więź między kobietami. Konsekwentne użycie rodzaju żeńskiego w wierszu Rimbaud do Verlaine'a (1997) pozwala widzieć w relacji miłosnej, zmityzowanej oczywiście, matrycę wszelkiej intymności wzbronionej; tu zarówno „ja”, jak i „ty” - świadczy o tym także tajemnicza dedykacja - są kobietami (pomijam fakt pewnej recepcyjnej niewiarygodności tonacji - raczej Verlaine pisałby tak do Rimbauda, nie odwrotnie):

wracam do ciebie

tylko bardziej zmęczona

tylko bardziej chora

zarażona szaleństwem

jedynym kompanem tego więzienia

popatrz co ze mną zrobili

bohatera z przełomu wieków

przez przypadek zostałam świętym

z seksownego ciała zostało ciało męczennika

na pamięć uczą się wszystkiego co mnie dotyczy

a przecież nie miałam ambicji zostać Chrystusem

nikogo nie zamierzałam zbawiać

nie podawałam się za króla

cechy nadczłowieka odziedziczyłam

nieświadomie po germańskich przodkach

chciałam spokojnie przejść przez życie

jak każdy mieć swoje słodkie grzechy

23 Biografka Verlaine’a przytacza słowa z listu Rimbauda: „nie będę przeszkadzał Panu więcej niż Zanetto; jestem tylko grudką brudu” (N, 79). To określenie typowe dla okolic zachodnich, obfitujących w czarny żużel - przypomina d'Eaubonne. 
w naiwny sposób stawać się coraz lepszym napisać o tym kilka milych wierszyków zrobić sobie parę potulnych dzieci nic nie robiłam za szybko a jeśli to spieszyłam się tylko do ciebie ${ }^{24}$

To, co nazywam apokryfem, a trafne byłoby też określenie „komentarz”, mieści się w prozie Sonnenberg zatytułowanej A moze ten statek nie byt pijany? (2007): długiej, porwanej na fragmenty, oddzielonej pisanymi kursywą cytatami (cudzym ale oswojonym - słowem) i refrenicznymi wstawkami z powracającym motywem chłodów (to aluzja do Rimbaudowskich „głodów”). Relacji Verlaine'a i Rimbauda dotyczą dwa fragmenty:

Przybywaj, wielka duszo, wzywamy cię czekamy.

Z listu Verlaine'a do Rimbauda

To nie Verlain ciebie uwiódł, ale Paryż. Paryż i czas. Światła w zaułkach uliczek, które były bardziej pijane od ciebie. Tamta chwila, gdy go po raz pierwszy zobaczyłeś. W snach? W myślach? W marzeniach? W wierszu? Jakbyś zniewolił strategię lustra. Powtarzalność, która jest tylko kolejnym odbiciem. Co bardziej widziałeś: Verlaina czy właśnie tę chwilę? Te wszystkie momenty, które złożyły się na wasze spotkanie. To nie Verlain ciebie uwiódł, ale ty Verlaina. Zresztą - czy to jest ważne? Właściwie nie wiadomo, co was bardziej łączyło: poezja czy ciało? Ale poezja staje się ciałem, a ciało poezją. Tekst jest ciałem, które upomina się o bliskość, o czułość, o zrozumienie, o pragnienie, o uczucie. Tekst, który uwodzi, kokietuje, pożąda, mami, oszukuje, żartuje. Ale twoje wiersze były jak celnie wymierzony cios. Żądła sprawiedliwości. Żądałeś od tekstu wiary w rzeczy niemożliwe, by przeobrażał się w kamień, którym mógłbyś rzucić w to, co święte, by płonął i płomieniem spopielał wszystko, co fałszywe. Pragnąłeś, by liście były fioletowe, a niebo płomieniem... I nie wiadomo, jakim sposobem teksty były ci posłuszne. Szły za tobą jak psy. Może dlatego od nich uciekłeś. Ten moment, gdy zapisane domaga się od nas jakiejś postawy: autentyzmu przeżyć. Zapisane dąży do jakiegoś komentarza, jakiegoś „tu i teraz”, jakiegoś natychmiast: jakby zatrzymania w pół biegu. Naraz zapisane staje się jak ręka, którą wyciąga w twoją stronę, abyś podzielił się sobą, abyś odstąpił jakiś fragment siebie. To moment, w którym zapisane zaczyna górować, zaczyna żyć s. 5 .

${ }^{24}$ E. Sonnenberg, Rimbaud do Verlaine'a, „Dekada Literacka” 1997, nr 4, 
własnym życiem, zaczyna nową opowieść o tobie. O tobie, który już jest kimś innym [podkr. - K.K.K.] ${ }^{25}$.

W tym fragmencie pojawiają się różne elementy Rimbaudowskiego mitu biograficznego: porzucenie poezji, skłonność do metamorfoz jako differentia specifica poety z Charleville (,ja to ktoś inny", zapowiedziane i wcielane w życie), Paryż (pijany, revolté) przeciwstawiony Francji (zbyt trzeźwej). Mnie jednak interesuje tylko to, co podkreśliłam: uwiedziony przez paryską ulicę Rimbaud uwodzi starszego o dziesięć lat Verlaine'a. I pytanie, które zawisa nad rozważaniami o tej erotycznej przyjaźni: poezja czy ciało? Czy była to bardziej przyjaźń intertekstualna, na co znaleziono już mnóstwo dowodów ${ }^{26}$, czy raczej (nie)porozumienie somatyczne? Ten dylemat pojawia się $\mathrm{w}$ drugim fragmencie u poetki, która zna zasadę nierozstrzygalności:

[...] kiedy włóczyliśmy się, nasyceni winem z pieczar $i$ sucharem wędrówki, spieszyłem się, by znaleźć miejsce i formułe

Spotkanie Verlaina i Rimbauda, które na zawsze zmieniło oblicze literatury. Co było istotą tego spotkania? Tysiące razy kogoś spotykamy, ale to nie jest spotkanie, raczej rodzaj mijania się. Kiedy następuje spotkanie, które jest olśnieniem, wybuchem, scaleniem? Spotkanie utkane ze współodczuwania, współbycia, współobcowania. Spotkanie, w którym słychać wołanie: będziemy braćmi, nigdzie niezakotwiczonymi. Nasze metafizyczne kryjówki nie zostaną odkryte, nasze przerażające pustelnie cuchnące brudem i nędzą, ślepy oczodół czasu nie zauważy naszej bajecznej samotności, naszej złowieszczej łamigłówki, bezbożnego rysowania znaków na płaskiej powierzchni zdarzeń, ubywający, zniekształceni, nieporuszeni. Odmieniając - nie odmieniamy. Nie odmieniając - odmieniamy. Z nakazem chwili, która wynurza się jak żarłoczny jęzor tygrysich skoków. Jego pazury jak słowa spływają krwią po naszych ciałach, te bolesne zadrapania obdarte $\mathrm{z}$ tego, co ludzkie. Nasze twarze obrzucimy obelgami tych, którzy łaszą się do naszych stóp. Będziemy brzemienni w odkrywanie nowych słów, brzemienni w rozpacze wyprowadzone na jałową ziemię wielkich miast $[\text { podkr. - K.K.K. }]^{27}$.

25 E. Sonnenberg, A może ten statek nie byt pijany?, „Pogranicza” 2007, $\mathrm{nr}$ 5, s. 23. Zachowałam autorską pisownię nazwiska Verlaine - Verlain.

${ }^{26}$ Najpełniej kwestiami intertekstualności wynikłymi z relacji Verlaine Rimbaud zajęli się według mojej wiedzy: C.A. Hackett, Verlaine et Rimbaud, w: Autour de Rimbaud, Paris 1967, s. 29-45; O. Nadal, op.cit., s. 35-43, 73-75, 154-155.

27 E. Sonnenberg, op.cit., s. 28. 
Sonnenberg jawi się spotkanie Verlaine'a i Rimbauda jako wielka obietnica, niemożliwa do spełnienia, ale $\mathrm{w}$ momencie prawdziwego spotkania jest przecież tylko obietnica (i właśnie jej nie ma, jak Beatrycze). Jeśli ktoś wiódł życie naprawdę cygańskie, we dwóch, jak we dwoje - to, przez pewien czas, Verlaine i Rimbaud.

Zakładam hipotezę, że teksty Sonnenberg zostały napisane po obejrzeniu filmu Agnieszki Holland, jedynej w swoim rodzaju mistrzowskiej dwubiografii ${ }^{28}$. Pierwszy z nich (wiersz) opublikowano bowiem w 1997 r., dwa lata po premierze Calkowitego zaćmienia (1995), drugi (proza) natomiast zdaje się pogłębionym odwołaniem do filmu - zmontowano go jakby z serii zahaczających o siebie obrazów.

Bruksela $^{29}$. Kto do kogo strzela w Brukseli? Uwiedziony do znudzonego uwodziciela? Pijany do trzeźwego? Kto okazuje się tu ofiarą, kto winowajcą? $3^{\circ}$ Może jest Bruksela negatywną odpowiedzią na pytanie Verlaine'a: „Czy ktokolwiek mógł mieć Rimbauda?” (N, 111)? Może Verlaine rzeczywiście upił się nie-

${ }^{28} \mathrm{Na}$ temat tego filmu zob. S. Bobowski, Calkowite zaćmienie [1995] nieuchronność $i$ tragizm buntu, w: W poszukiwaniu siebie. Twórczość filmowa Agnieszki Holland, Wrocław 2001, s. 241-260. Streszczam interesujący mnie rozdział, podkreślając kwestie najistotniejsze. Monografista postrzega ten film jako antytezę Tajemniczego ogrodu, pisze o przywołaniu czarnej legendy biograficznej Verlaine'a i Rimbauda, patologicznej relacji sadomasochistycznej (Piekielny Oblubieniec i Panna Głupia z Sezonu w piekle Rimbauda), a jednocześnie dostrzega w sposobie opowiadania tej historii oszczędność, precyzję, brak gadulstwa, przekonującą i wzruszającą opowieść o homoseksualizmie. Holland jest jak Szekspir, powiada Bobowski: „uwydatnia uzależnienie człowieka od sił, którymi nie może władać”; moralność ekstazy (orgie, dionizyjskość) przeciwstawia się tu moralności procesu: „Bez Rimbaudów ludzkość nie wiedziałaby o pustce, która czai się za kulturową grą pozorów [podkr. K.K.K.]” (s. 255). Rimbaud i Verlaine - wielcy, nieszczęśliwi, okrutni - kochają się i niszczą wzajemnie. Bobowski zadaje pytanie o tożsamość bohaterów dramatu: Rimbaud - kim jest? - prekursorem buntowników i poetów nowoczesnych, tym, który potrafi zapisać niewyrażalne; Verlaine - kim jest? niezrównoważonym alkoholikiem z kompleksem brzydoty, uzależnionym od absyntu - to typowy homo duplex. Autor książki podkreśla specyfikę prezentowanej relacji erotycznej - zaślepienie, odurzenie, asymetrię; za punkt zwrotny uznaje tragedię w Brukseli. Całkowite zaćmienie to, mówiąc językiem Gombrowicza, opowieść o epoce Synczyzny", pojawia się tu archetyp dziecka jako enfant terrible (dodałabym - dziecka opisanego przez Rimbauda w wierszu Siedmioletni poeci). Por. też Czarna legenda poety przeklętego [rozmowa z Agnieszką Holland], „Kino” 1995, nr 4, s. 4; M. Jankun-Dopartowa, Dialektyka Narcyza i Ikara, „Kwartalnik Filmowy” 2001, nr 33, s. 40-62.

${ }_{29}$ Szczegółowy przebieg dramatu brukselskiego przedstawił W. Kalicki w artykule 10 lipca 1873 - zastrzel mnie!, „Duży Format” [dodatek], „Gazeta Wyborcza”, 11 lipca 2005.

$3^{\circ}$ Zob. J.M. Carré, Le drame de Bruxelles, w: La vie aventureuse de Jean- Arthur Rimbaud, Paris 1949, s. 105-118. 
rozważnie mijającym go cieniem, którego Stéphane Mallarmé, mając w pamięci Zanetta, nazwał „znakomitym przechodniem” (N, 110)? W filmie Holland rana postrzałowa Rimbauda „rymuje się” z pierwszą nocą kochanków w paryskiej mansardzie przy ulicy Campagne-Première - tą nocą, po której nad ranem Verlaine otrzymał list separacyjny od Matyldy, a Rimbaud napisał słynny erotyk:

L'étoile a pleuré rose au coeur de tes oreilles, L'infini roulé blanc de ta nuque à tes reins

La mer a perlé rousse à tes mammes vermeilles

Et l'Homme saigné noir à ton flanc souverain ${ }^{3}$.

Gwiazda w muszli twych uszu płakała różowo,

Bezkres biało z twych ramion na biodra się stoczył,

Morze spłoniło wzgórza twych piersi perłowo,

A Człowiek na twem łonie czarno krwią się zbroczył32.

W Brukseli „strzelił doń w uniesieniu” 33 - napisał Leopold Staff w nocie biograficznej Rimbauda, nie wyjaśniając, skąd pomiędzy przyjaciółmi nagłe „uniesienie”. Być może jednak tym silnie nacechowanym słowem zasugerował więcej, niż można było powiedzieć w Polsce w roku 1924. O relacji poetów-kochanków - także w biogramie Verlaine'a - napisał Boy:

Urodzony w r. 1844, bardzo brzydki, o słabej i pobudliwej naturze, wcześnie zdradzający skłonność do kieliszka, Paweł Verlaine żeni się

$3^{1}$ OC, 170; podkr. - K.K.K.; komentarze: OC, 877-878. Kopia Verlaine'a. Wiersz bez tytułu, znany również jako Madrygał. Pierwszy wers jest aluzją do wersu Leconte de Lisle'a: „La femme a pleuré mort le meilleur de sa chair” z La Fin de l'bomme (1858). Oprócz erotycznej wskazywano również na możliwość interpretacji heraldyczno-alegorycznej: kolory umieszczone konsekwentnie w zakończeniach kolejnych hemistychów tworzą herb (trzy pierwsze odnoszą się do życia, ostatni - kontrastowo - do śmierci), a nawet politycznej (w odniesieniu do klęski Komuny Paryskiej). Por. Y. Reboul, Quelques mots sur „L'étoile a pleuré rose...”, „Rimbaud vivant” 2001, nr 40, s. 12-25.

$3^{2}$ J.A. Rimbaud, Czterowiersz, przeł. J. Tuwim, w: Poezje, Warszawa 1921, s. 63. Na temat tego przekładu zob. M.J. Woźniak, Juliana Tuwima przekłady z Rimbauda. Kilka uwag o przekładach wierszy „Czterowiersz”, „Kredens”, „Moja bohema” oraz „Głowa Fauna”, w: Julian Tuwim. Biografia. Twórczość. Recepcja, red. K. Ratajska i T. Cieślak, Łódź 2007, s. 183-185. Wiersz Rimbauda przełożyli również: J.W. Gomulicki oraz J. Kolankowski. Zob. J.W. Gomulicki, Zygzakiem. Szkice. Wspomnienia. Przekłady, Warszawa 1981, s. 367-368; A. Rimbaud, Stońce $i$ ciało, wybór, przeł. J. Kolankowski, Jelenia Góra 1992, s. 25 (przedruk w: J.A. Rimbaud, Dzieła, przeł. J. Kolankowski, Kraków-Jelenia Góra [b.d.], s. 111).

33 Lirycy francuscy. Wybór poezji: od XII do XX wieku, wydał i przypisami opatrzył L. Staff, Warszawa 1924, s. 647-648. 
w 1871 roku z panienką z mieszczańskiej sfery. Już wskutek wymienionych właściwości charakteru poety małżeństwo to utyka, zupełne jego rozbicie sprowadza wpływ młodego Artura Rimbaud, genialnego wyrostka, który potrafił zupełnie owładnąć słabym poetą. Verlaine wałęsa się z młodym cyganem po Anglii i Belgii; w Brukseli przychodzi między nimi do gwałtownej sceny, w czasie której Verlaine, pod wplywem trunku strzela (nieszkodliwie zresztą) do Rimbauda [podkr. - K.K.K.]34.

Boy pisze nieco jaśniej niż Staff, ale w dalszym ciągu owo „przychodzi między nimi do gwałtownej sceny” nie wyjaśnia istoty intensywności relacji poetów.

Nieoczekiwanie, chyba dla samego siebie, po stronie Rimbauda jako dżentelmena (sic!) opowiada się Karol Wiktor Zawodziński. Jego wywód na temat Verlaine'a jest sarkastycznym oskarżeniem rzuconym niekoherencji życia i tworzenia (podobnie wiele lat później Tadeusz Różewicz będzie oskarżał Rilkego) - taki zarzut wobec Rimbauda byłby rzeczywiście niemożliwy:

Tak, wobec lirycznego „ja” jednego z najsubtelniejszych poetów świata Verlaine'a, który uwiecznotrwalił najzwiewniejsze, najwznioślejsze i najczystsze drgania duszy człowieczej, cóż znaczą jego grzechy ziemskie? [...] Ale wyobraźmy sobie, że Verlaine nie był poetą, tylko zwykłym panem Verlaine'em, którego sądzimy wyłącznie podług dokumentów jego życia $[. .$.$] , nie przełamując widzenia$ poprzez kryształ jego poezji: nie tylko alkoholik i zboczeniec, potworny syn $[\ldots]$, potworny mąż, cudem tylko nie matkobójca i nie żonobójca, ale w dodatku tchórz i dezerter z frontu, urzędnik komuny ukrywający się potem przed odpowiedzialnością, pisarz eksploatujący literacko równocześnie „,poryw ku świętości” i skłonności do pornografii, kara więzienia, którą odsiedział za dwukrotne premedytowane usiłowanie zabójstwa przyjaciela, była karą tylko dlatego tak łagodną, że i świadek (matka), i poszkodowany starali się wybielić wbrew faktom zbrodniarza: w tym wypadku Rimbaud (zresztą nieprawdopodobny typ chuligana w stylu rosyjskim, może dlatego tak imponujący na gruncie francuskim [...]) w tym wypadku ujawnił wysoką dżentelmenerię 35 .

Wyobraźmy sobie bardzo długowiecznego, a nieobarczonego zanikiem pamięci, polskiego czytelnika Rimbauda, który poznał wersję Boya o strzałach niegroźnych, wynikających z upojenia al-

${ }_{34}$ T. Żeleński (Boy), Antologia literatury francuskiej, w: Pisma, t. 14, Warszawa 1958, s. 636-637.

35 K.W. Zawodziński, Jeszcze jedna odpowiedź, „Zet” 1934, nr 14, s. 2. 
koholowego i rozpaczy, oraz wersję Staffa (uniesienie), wreszcie wersję Zawodzińskiego (dwukrotne usiłowanie zabójstwa z premedytacją) - urodzonego w roku 1905 czytelnika, który w 1995 wybrał się do kina na film Agnieszki Holland. Zobaczył medykalizację i penalizację związku homoerotycznego - jedna z najbardziej drastycznych scen filmu to badanie odbytu Verlaine'a przeprowadzone w całym majestacie władzy lekarskiej i policyjnej, by potwierdzić jego czynny homoseksualizm (wtedy zwany sodomią, a więc traktowany jak stosunki fizyczne ludzi ze zwierzętami). Zobaczył, jeśli czytał coś innego niż dzieła Rimbauda i Verlaine'a, zobaczył jasno Renégo Girarda i Michela Foucaulta, zwłaszcza tego drugiego z Nadzorować $i$ karać. Wtedy zapewne, mimo tęgiej głowy, zmarł na zawał serca ów dziewięćdziesięciolatek - tak bardzo dzisiejsze postrzeganie dramatu w Brukseli różni się od tego w poprzednim półwieczu.

Gertrudes Johannes Resink wysunął kontrowersyjne przypuszczenie, iż „dramat, jaki rozegrał się pomiędzy Verlaine'em a Rimbaudem w Brukseli, znajduje swą transpozycję na wyspie Samburan w powieści Conrada Zweycięstwo" ${ }^{36}$. Wobec tej koncepcji dystansuje się tłumaczka tekstu Resinka, autorka kilku szkiców o Josephie Conradzie ${ }^{37}$, a mówiąc „my”, powołuje się na autorytet męża, tłumacza i wydawcy Rimbauda, Jarosława Iwaszkiewicza:

Zważywszy nawet pewne zbieżności w ich naturze, a także pewne analogie sytuacyjne, uważam, że zestawienie pary wielkich poetów, Verlaine - Rimbaud, z parą awanturników i notorycznych bandytów, jakimi są Jones i Ricardo ze Zwycięstwa, wzbudza głęboki sprzeciw i niesmak. Para ta przypomina raczej inną parę literacką, mianowicie Płazę-Spławskiego i Pochronia z Dziejówe grzechu Żeromskiego (toutes proportions gardées). Pamiętam, że swego czasu, kiedy wyszło Zreycięstwo, mówiliśmy o tym i zastanawialiśmy się, czy Conrad znał już wtedy Dzieje grzechu i czy jest możliwe [Dzieje grzechu wydano w roku 1908; Zwycięstwo powstawało w latach 1912-1914], żeby te postacie zostawiły w nim pewien ślad na pewno nieświadomy, ale dość silny, by kiedyś przyczynić się do powstania postaci Jonesa i Ricarda. [...] Zastanawiający jest zresztą fakt, że sam autor pod koniec eseju przyznaje, że porównanie Rimbauda z Ricardem jest czymś „nieco niepoważnym” ${ }^{8}$.

${ }^{6}$ G.J. Resink, Axel Conrad i Martin Rimbaud, przeł. A. Iwaszkiewiczowa, „Twórczość” 1972, nr 6, s. 85.

37 Zob. A. Iwaszkiewiczowa, Conrad i Proust. Sztuka Conrada, w: Szkice i wspomnienia, do druku podała M. Iwaszkiewicz-Wojdowska, wstęp P. Hertz, Warszawa 1987.

${ }^{8}$ A. Iwaszkiewicz, Od thumaczki, w: G.J. Resink, op.cit., s. 89-90. 
Istnieją $\mathrm{w}$ polskiej poezji dwa wiersze nie tylko zatytułowane Bruksela, ale wyraźnie sugerujące odniesienia Rimbaudowskie: Iwaszkiewicza z tomu Powrót do Europy (1931), opatrzony mottem „Bruksela. Bulwar Regenta...” ${ }_{39}$ (przekładem epigrafu do Rimbaudowskiej Bruxelles $4^{\circ}$ : „Juillet. Boulevard ${ }^{4 \mathrm{I}}$ de Régent”) oraz Stefana Napierskiego - utwór z 1935 r., zawierający parentetyczny podtytuł (Pamięci J.A. Rimbaud) ${ }^{42}$. Napierski był także thumaczem Rimbaudowskiej Brukselił3 (by łatwiej identyfikować tekst, używam przez chwilę niegdysiejszego tytułu).

Rimbaud zamieścił przy wierszu informację o czasie powstania: „juillet”, ale - ponieważ Verlaine i Rimbaud przebywali w tym belgijskim mieście zarówno w lipcu 1872 r., jak i w feralnym lipcu 1873 r. - niestety, nie wiadomo, który lipiec jest tu bohaterem poetyckim (OC, 906). Trudno również wskazać, do którego lipca odnoszą się Iwaszkiewicz i Napierski. Pozostańmy przy spostrzeżeniu, że czynią aluzję do wiersza Rimbauda i nakładają nań swą biograficzną wiedzę o dramacie z 1873 r.

Iwaszkiewicz:

Grzechot gniewliwy głuchych tłumów,

Łomot pociągów - i twój wzrok,

Wszystko się miesza bez rozumu,

Gdy słucham szczęku uczonych fok.

Północne niebo deszczem ślini

Na twoich wspomnień złoty dysk.

Lecz próżno szczerzą Fratellini

W uczonym cyrku krowi pysk...

I chociaż miażdży mnie Bruksela,

Tramwajów szczekających rząd,

I choć się „duch” nie „przeaniela” -

Czuję w mej krwi gorący prąd.

39 J. Iwaszkiewicz, Bruksela, w: Powrót do Europy, Warszawa 1931, s. 45.

$4^{\circ}$ Precyzyjniej byłoby powiedzieć: wiersza, który dawniej identyfikowano pod tym tytułem; według najnowszych ustaleń nie należy utożsamiać epigrafu z ewentualnym tytułem - dlatego wydawca wszystkich pism Rimbauda z 2009 r. proponuje najwcześniejszą z tradycji edytorskich i tytułuje wiersz według incipitu: Plates-bandes d'amarantes... (OC, 222-223, komentarz: 906-907).

${ }^{41}$ Zob. OC, 222; komentarz: 907; obecnie przyjmuje się pisownię „boulevart”, zgodną z uzusem XIX-wiecznym.

$4^{2}$ S. Napierski, Bruksela (Pamięci J.A. Rimbaud), „Miesięcznik Literatury i Sztuki” 1934/1935, nr 9, s. 259.

43 Pierwodruk tego przekładu w: S. Napierski, Od Baudelaire'a do nadrealistów. Przektady i szkice z nowoczesnej literatury francuskiej, Warszawa 1933, s. 73-74. 
I - o wiele bardziej uwydatniając negatywne emocje Napierski:

Złe miasto, gdzie, ściągnąwszy brew,

Błądziłeś, czuły i szalony,

O, chłopcze! znów smakuję krew,

$\mathrm{Na}$ wargach nalot słony.

Opadał zdarty mściwie głos

I rudy kosmyk ponad czołem, Jak struna rdzawa, plącząc włos

Z złym, kudłatym aniołem.

Wokoło skroni chudych bił

Płomyk, jak pyton metaliczny,

Z dymiących trzew, z rozdartych żył

Piał twój jęk krystaliczny.

Gdy w podniebieniu tkwiący grot

Zeszywał zielonkawe chmury,

Nad Panteony wznosząc młot,

Targałeś tkliwe struny.

Ponury, w kułak zwarłszy pięść,

Kąsając wargi i wybladły,

Rozbłyskiem zębów rwałeś więź -

Patrz! rdzawe liście spadły...

Crimen amoris i Sezon w piekle. Z biograficznego oraz intertekstualnego punktu widzenia zbudowany z 25 strof poemat Verlaine'a (rozmiar Statku pijanego) oraz skonstruowane z poematów prozą dzieło Rimbauda tworzą bliźniaczą parę tekstów - rewers i awers tych samych zdarzeń. Ten sam czas przywołują zupełnie inaczej: biografizm lektury Une Saison en enfer i późnych wierszy Verlaine'a poświęconych Rimbaudowi jest hipotezą konieczną.

Verlaine pisał Zbrodnie mitości w więzieniu latem 1873 r., wielokrotnie ją poprawiał i przerabiał. Może dziwniejsze od samego Crimen amoris (zalegoryzowanej historii Rimbauda BN II 200, 143) jest to, czym został napisany: „, na papierze z opakowań zapałką maczaną według jednej wersji w kawie, według innej - w konspiracyjnie przechowywanym w szparze podłogi atramencie" (BN II 200, 142). Ale wybór metrum - rzadkiego w poezji francuskiej jedenastozgłoskowca (u Verlaine'a to jedy- 
ne użycie tego rozmiaru) - podkreśla pojedynczość tego „misterium” czy tej „wizji” (takie podtytuły w rękopisach - BN II 200, 143). Gdyby porównać narysowany tu portret Rimbauda z tymi z drugiej połowy lat 80., w Poetach przeklętych albo w Laeti et errabundi widać jeszcze świeżą ranę i leksykę nawracającego się grzesznika (cytuję w przekładzie Anny Drzewickiej):

Zaś najpiękniejszy z wszystkich tych złych aniołów

Miał lat szesnaście, na skroniach z kwiatów wieniec

Ramiona skrzyżowawszy i chyląc czoło

Marzy, a w oczach jego łzy i płomienie. (BN II 200, 143)

Schwarzwald/Stuttgart. Rimbaud wyjechał w styczniu 1875 r. do Niemiec, gdzie udzielał lekcji francuskiego jako nauczyciel domowy w Stuttgarcie; 16 stycznia Verlaine opuścił więzienie w Mons i, świeżo nawrócony, odwiedził przyjaciela. Piszą na ten temat Julia Hartwig i Artur Międzyrzecki:

przeżył wstrząs duchowy, powrócił do praktyk religijnych i pragnie oddziałać w tym kierunku na Rimbauda. Misja Verlaine'a kończy się fiaskiem. Rozmawiają o literaturze, wręczają sobie manuskrypty (Verlaine otrzymać ma wówczas od Rimbauda rękopis Iluminacji...), później jednak dochodzi między nimi do gwałtownej sprzeczki i nawet - jak przypuszczają niektórzy z biografów - do bójki. Verlaine wyjeżdża ze Stuttgartu po dwudniowym pobycie. Widzą się wówczas po raz ostatni ${ }^{4}$.

Jules Renard, czyniąc aluzję do tego spotkania, wybiera niedaleki Schwarzwald (Czarny Las) zamiast Stuttgartu, by móc wygrać znaczenia symboliczne (Czarny Las - Czarna Bestia): „Verlaine zaatakowany przez zwierzę w Czarnym Lesie: poznaje Rimbauda. A jeśli nie był to Czarny Las, to może był jeszcze od niego czarniejszy" (D, 41, 22 stycznia 1893)45.

Dwie wiadomości o śmierci Rimbauda. Gdy policzy się wszystko, co Verlaine napisał o Rimbaudzie, gdy doda się wiersze, krótsze i dłuższe, Poetów przeklętych, listy - aż przychodzi chęć, by zawołać, parafrazując Cwietajewą: taki rozmach w przyjaźni nie jest dany. W sposób szczególny potwierdzają to

44 Ja to ktoś inny. Korespondencja Artura Rimbaud, wybór, przel., oprac. J. Hartwig, A. Międzyrzecki, Warszawa 1970, s. 109.

45 W oryginale: „Verlaine attaqué par une bête dans la Forêt-Noire: il a reconnu Rimbaud. Et, si ce n'était la Forêt-Noire, elle était peut-être plus noire qu'elle" (J, 147, 22 janvier 1893). 
reakcje Verlaine'a na wieść o śmierci Rimbauda - najpierw na pogłoskę o rzekomej śmierci, potem na wiadomość o rzeczywistym zgonie.

W długim wierszu Laeti et errabundi (OPC, II, 195-199) $\mathrm{z}$ tomu Parallèlement ${ }^{46}$ - aż 25 strof (tyle strof miał Statek pijany - najdłuższy wiersz Rimbauda! 47 ) - starszy poeta starał się przywołać - jak pisze Drzewicka - „wciąż żywe wspomnienie związku z Rimbaudem i niezwykłej przygody, która była także przygodą duchową i poetycką" (BN II 200, CIV). Wiersz powstał w lipcu 1887 r. pod wpływem plotki o śmierci przyjaciela. Verlaine pisze w nim o dawnym kochanku „z żarliwym entuzjazmem”: „le roman de vivre à deux hommes”, „Scandaleux sans savoir pourquoi/ (Peut-être que c'était trop beau)" [OPC, II, 197; „powieść życia dwóch mężczyzn” lub „powieść życia we dwoje”; „Skandaliczny, nie wiedzieć dlaczego/ (Być może to było zbyt piękne)"]. Wspomina dawne, wspólne, cygańskie życie (szalone pijaństwo, kiedy „dusza porwana do siódmego nieba”, a „ciało, skromniejsze, pod stołem” - OPC, II, $\left.196^{48}\right)$, przeciwstawia je mieszczańskiej stabilizacji Paryża, gdzie pozostawił „certaine princesse Souris” - „niejaką księżniczkę Myszkę”. Nie przyjmuje pogłoski, nie przyjmuje jej w bardzo pięknym stylu:

On vous dit mort, vous.

[...

Je n'y veux rien croire. Mort, vous,

Toi, dieu parmi les demi-dieux!

Ceux qui le disent sont des fous!

Mort, mon grand péché radieux

[...

Quoi! le miraculeux poème

Et la toute-philosophie,

${ }^{46}$ Wszystkie oryginalne cytaty z Verlaine'a pochodzą z edycji: P. Verlaine, Oeuvres poétiques complètes, oprac. Y.G. Le Dantec, t. 1-5, Paris 1955. Stosuję skrót OPC z numerem tomu i strony.

47 Można by tę analogię rozbudować interpretacyjnie, na co nie mam tu miejsca: obydwa wiersze składają się ze strof 4 -wersowych, obydwa za temat obierają „pijane wędrowanie”, wreszcie wiersz Laeti et erranbundi - co potwierdzałoby świadome nawiązanie Verlaine'a do najsłynniejszego poematu Rimbauda (zatem nawiązanie czytelne dla potencjalnych odbiorców) - jest wzmocniony również 25-zwrotkowym Crimen amoris. Tak jakby rozmiar Rimbaudowski u Verlaine'a obejmował 25 strof.

$4^{8}$ Przeł. K.K.K. W oryginale: „L'âme au septième ciel ravie, / Le corps, plus humble, sous les tables". 


\section{Et ma patrie et ma bohème}

Morts? Allons donc! tu vis ma vie! (OPC, II, 199)49

Czy ktoś, poza zakochanym, może nazwać utraconego podwójnie przyjaciela „bogiem pomiędzy półbogami”, „swoim wielkim promiennym grzechem"? Tego samego przyjaciela, który go pobił, który wyśmiał jego nawrócenie5० (Panny Głupiej z Sezonu w piekle) i pojechał na koniec świata (Piekielny Oblubieniec)?

Drugi raz już nie pomogło zaklęcie; po prawdziwej śmierci Rimbauda Verlaine napisał sonet, którego tytuł i podtytuł w pierwodruku („La Plume”, 15 lutego 1893) brzmiały: A Arthur Rimbaud, d'aprés un dessin de sa soeur le représentant en costume orien$\mathrm{tal}^{\mathrm{I}}$. Rysunek siostry Izabeli był zaopatrzony w epigraf z $\mathrm{Se}$ -

49 Nie odnalazłam polskiego przekładu tego ważnego wiersza, nie wydaje mi się, aby tłumaczenie filologiczne było tu dobrym wyjściem z patowej sytuacji. Zamiast niego proponuję krótką opowieść ( $\mathrm{z}$ elementami translacji) o zamieszczonym fragmencie: Verlaine nie może uwierzyć - skądinąd jego intuicja jest niezawodna - w śmierć dawnego kochanka, gdyż nie umiera „bóg pomiędzy półbogami” („dieu parmi les demi-dieux”), a ci, którzy tak twierdzą, są szaleńcami („Ceux qui le disent sont des fous!”). Porzucony przyjaciel nie daje również wiary w śmierć wszystkiego, co ich łączyło - poezji, filozofii, bohemy jako ojczyzny (przejmująca fraza przerzutniowa: „Et ma patrie et ma bohème/ Morts?”). Verlaine z właściwą sobie emfazą wykrzykuje, że Rimbaud żyje jego życiem („tu vis ma vie!”). Najciekawsze są jednak losy wersu puentowanego niedowierzaniem w następnej strofie: „Mort, mon grand péché radieux” („Umarły, mój wielki promienny grzech”). Otóż w takim brzmieniu umieścił go, pomijając słowo „mort”, V. Nabokov w tym miejscu Lolity, gdy Humbert spotyka swą kochankę nimfetkę już jako zabiedzoną mężatkę, spodziewającą się dziecka, wciąż jeszcze bardzo młodą: „Owoc, który dotychczas hołubiłem wśród splątanych pnączy mego serca, mon grand péché radieux, skurczył się pozostawiając samą esencję: a jałowy i samolubny występek - ten przekreśliłem i przekląłem. Możecie ze mnie drwić, możecie grozić, że usuniecie publiczność, lecz póki nie mam knebla w ustach, póki nie jestem na wpół uduszony, będę wykrzykiwał swą biedną prawdę. Żądam, żeby świat dowiedział się, jak bardzo kochałem moją Lolitę, tę Lolitę, bladą i zbrukaną, brzemienną cudzym dzieckiem, ale wciąż jeszcze szarooką, sadzorzęsą, kasztanową i migdałową". Nieco dalej mowa o tym, że Lolita jest „nieśmiertelną nieżywą ukochaną”. V. Nabokov, Lolita, przeł. M. Kłobukowski, Warszawa 1997, s. 336, 339. Oczywiście, Verlaine i bohater Nabokova są w tej samej sytuacji egzystencjalnej - niedowierzania, poczucia winy i wewnątrz niegasnącego uczucia.

50 Rimbaud drwił z nawrócenia Verlaine'a, które uważał za przejściowe, w liście do E. Delahaye'a, wysłanym ze Stuttgartu 5 marca 1875 r., pisał: „Verlaine przyjechał tu któregoś dnia z różańcem w rękach... Trzy godziny później wyparliśmy się jego boga i rozkrwawili 98 ran Naszego Pana”. Ja to ktoś inny, op.cit., s. 110-111.

${ }^{\text {I }} \mathrm{W}$ kolejnych wydaniach pozostał tylko tytuł $\mathrm{z}$ informacją umieszczoną poniżej: „Sur un croquis de lui par sa soeur”. Sonet, znany później jako $A A r-$ thur Rimbaud (II), w odróżnieniu od sonetu A Arthur Rimbaud (I)drukowanego w „Le Chat noir” 17 sierpnia 1889 r. - którego pierwszy wers „Mortel, ange ET 
zonuwpiekle: „Des climats perdus me tanneront” (OPC, IV, 286) $)^{2}$. $\mathrm{Na}$ szczególną uwagę zasługują dwie pierwsze strofy, pełne autentycznego wzruszenia i niepohamowanego żalu („Toi mort, mort, mort!” - „Ty martwy, martwy, martwy!”; OPC, IV, 80) oraz wers ostatni, będący próbą pogodzenia z Bogiem tego, który sam się nie pogodził ("Rimbaud! pax tecum sit, Dominus sit cum te!” - „Rimbaud! Pokój niech będzie z toba, Pan niech będzie z Tobą!"; OPC, IV, 80).

Znając dwa najważniejsze teksty poetyckie Verlaine'a o Rimbaudzie, Laeti et errabundi oraz Crimen amoris - obydwa 25-zwrotkowe - zatem szyte na miarę Statku pijanego, d'Eaubonne skonstruowała taki oto emfatyczny monolog lament starszego poety:

Kim byłem? Byłem żonaty z kobietą, którą kocham..., miałem stanowisko, ładne mieszkanie, rodzinę. Byłem dobrze ubrany, miałem czyste paznokcie; najadałem się do syta; obracałem się w doskonałym towarzystwie, wśród inteligentnych przyjaciół. Kim się stałem? Kimś, kto się błąka. Kimś rozrzuconym po wszystkich falach grzechu! Dusza moja szykuje się do odpłynięcia w podróż katastrofalną... Statek pijany to ja... (N, 176-177, podkr. - K.K.K.)

Recepcja wątku intimité Verlaine'a i Rimbauda jest różnorodna. Pojedyncze zdania i krótkie wypowiedzi sąsiadują tu ze skomplikowanymi tekstami. Pojawiają się echa tej jedynej w swoim rodzaju relacji w dzienniku Renarda, w zapiskach Boya, w Staffowskim biogramie, w opiniach krytycznych Zawodzińskiego, w tłumaczonym przez Czesława Miłosza wierszu Conrada Aikena53, w filmie Holland, w poetyckiej parafrazie

démon, autant dire Rimbaud" (OPC, IV, 79) z podpisem autora współtworzył legendę Rimbaudowskiego portretu Paterne'a Berrichona. Por. OPC, IV, 285.

${ }^{2}$ Całe zdanie w oryginale brzmi: „L'air marin brûlera mes poumons; les climats perdus me tanneront" (OC, 249), a w polskim przekładzie A. Międzyrzeckiego: „Morski wiatr wypraży moje płuca; wygarbują mi skórę egzotyczne klimaty”. A. Rimbaud, Wierszee. Sezon w piekle. Iluminacje. Listy, tlumacze różni, wybór, oprac., posłowie A. Międzyrzecki, Kraków 1993, s. 161.

53 Pierwodruk: C. Aiken, Rimbaud $i$ Verlaine, dwaj cenni poeci, przeł. C. Miłosz, „Kronika”, [Łódź] 1957, nr 2, s. 5. Przedruk z ciekawym komentarzem translatorskim w: C. Miłosz, Kontynenty, Kraków 1999, s. 415-417. Miłosz pisze, że wiersz „zawiera w skrócie przygody literackiej awangardy od Rimbauda. W buncie przeciwko retoryce są jakby dwa piętra i obawiać się można, że wielu (przede wszystkim Francuzów) zatrzymało się na piętrze subiektywnym - u Aikena jest już jakby bunt przeciwko buntowi (dość dialektyczny)” (s. 415). Tekstu wiersza nie przytaczam w całości ze względu na jego rozmiary. Utwór ma charakter demityzujący wobec legendy biograficznej („I Verlaine umarł - czerń, liliowość na nic./ I Rimbaud umarł, w Marsylii, z wizjami”; „Verlaine i Szekspir, niech, gdzie leżą, gniją./ Pamięć Rimbauda 
i w prozatorskim apokryfie Sonnenberg oraz - na prawach hipotezy - w Zwycięstwie Conrada. I jeszcze w jednym miejscu, które chciałabym wyróżnić.

\section{Rimbaud - diabeł stróż}

Listy Czajkowskiego i Janowskiej mają prócz wartości własnej, immanentnej szczególną wartość jako epilog snutych tu refleksji: tytuł nadany całej korespondencji nawiązuje do jednej z wypowiedzi polskiego kompozytora: „Ty wiesz, że Rimbaud to mój diabeł stróż" (MDS, 273; 9 października 1979). Przytaczam większy fragment tego listu, który oprócz skojarzeń z piosenką Jonasza Kofty Rimbaud, Aniele Stróżu mój ${ }^{4}$ oraz - najbardziej oczywistego kulturowo - z pytaniem Kaina ${ }^{55}$, świadczy dobitnie o tym, jaki był stosunek Czajkowskiego do postaci Rimbauda (diaboliczność jest Verlaine'owskim rysem w opisie poety z Charleville):

Mój przyjaciel Jaś Pęski [...] zrobił z fotografii Rimbauda dwa wręcz niesamowite portrety, zaznaczył przy tym na wystawie, że nie są do sprzedania, mimo to zostały szczególnie wyróżnione w krytyce, teraz dał mi je w prezencie! Jestem oszołomiony - Ty wiesz, że Rimbaud to mój diabeł stróż... Teraz namawiam Jasia, aby namalował Wielkiego Inkwizytora z Braci Karamazow. (MDS, 273)

Bo rzeczywiście, $\mathrm{w}$ tym romansie epistolarnym ${ }^{56} \mathrm{Rimbaud}$ zajmuje miejsce nie tylko pretekstowe. Listy Czajkowskiego

jest sprawą niczyją”), wykorzystuje przewrotnie topos gry w szachy jako gry z losem o własne życie i znaczenie. Wątkiem powracającym jest antyretoryczny charakter poezji nowoczesnej - skręcanie karku retoryce łączy się tu z braniem boskości za gardło - z odrzucaniem dotychczasowych, tradycyjnych autorytetów (Bóg, retoryka). Wydaje się, że Miłosz nieprzypadkowo przetłumaczył ten wiersz Amerykanina, sam doceniał (o czym świadczą zapiski w Roku myśliwego z 23 listopada 1987 r. oraz 7 stycznia 1988 r.), ale nie przeceniał Rimbauda, czemu dał wyraz w haśle osobowym z Innego abecadła. Zob. C. Miłosz, Rok myśliwego, Kraków 1991, s. 142, 178; idem, Inne abecadło, Kraków 1998, s. 129-133.

54 J. Kofta, Rimbaud, Aniele Stróżu mój, w: Godzina cienia, Kraków 2004, s. 92-93. Piosenka, do której muzykę napisał J. Loranc, była wykonywana w kabarecie „Hybrydy” (powstała między 1957 a 1968 r., zatem Czajkowski, piszący przywoływany list dekadę później, mógł ją znać).

55 Rdz 4, 8-9: „Kain zwrócił się do swego brata, Abla. A gdy byli na polu, Kain rzucił się na swego brata, Abla, i zabił go. Wtedy Bóg zapytał Kaina: «Gdzie jest brat twój, Abel?». On odpowiedział: «Nie wiem. Czyż jestem stróżem brata mego?»”. Biblia jerozolimska, Poznań 2006, s. 18.

${ }^{6}$ Posługuję się tu określeniem J. Zielińskiego, użytym w stosunku do korespondencji Rilkego, Cwietajewej i Pasternaka. J. Zieliński, Listy troiste, „Zeszyty Literackie” 1986, nr 14. 
z dwóch następnych lat - 1980 i 1981 - przynoszą zrazu entuzjastyczny projekt napisania opery inspirowanej Sezonem w piekle oraz sztuką Christophera Hamptona Total Eclipse, później $\mathrm{z}$ wolna zarzucany i już nigdy niepodjęty (pianista urodzony w 1935 r. zmarł 26 czerwca 1982 r. w Oksfordzie):

Pamiętasz, jak zżymałem się na Hamptona (autora owej sztuki o Rimbaudzie), że nie chce się ze mną spotkać? Po dwóch latach doszedł do wniosku, że jednak to jest już możliwe i potraktował mnie od razu jak starego, zaufanego przyjaciela, spędził ze mną całe popołudnie i zgodził się z góry na wszystko, co mam zamiar $\mathrm{z}$ jego sztuką zrobić. Dawno już napisałem mu, że chcę ją powiązać z autobiograficznym poematem Rimbauda Sezon w piekle, i Hampton, mimo że nadal nie proponował spotkania, przetłumaczył dla mnie na angielski wiele stron tego poematu - całe wieczory pracy, za którą nikt mu nigdy nie zapłaci! Ale wiesz, co myślę o najlepszych nawet przekładach poezji, zawsze muszą być lepszą lub gorszą imitacją oryginału, a ryzyko jest tym większe, im genialniejsza poezja. Wpadłem więc na inny pomysł: może by zrobić całą operę po francusku, tak, aby teksty Rimbauda były w oryginale? Znów się od razu zgodził, ale uprzedził mnie, że przekład francuski okazał się nie najlepszy. „How is your French?” - zapytał. Więc z wielkim podnieceniem zabrałem się do thumaczenia Total Eclipsena francuski, co jest dla mnie zupełnie nowym przedsięwzięciem. (MDS, 342-343; 16 listopada 1981, podkr. - K.K.K.)

Jeśli trafisz kiedyś na [...] Życie pana Moliera, to bądź tak dobra i mi przyślij. [...] to bodaj że lepszy temat do opery niż Rimbaud. (Sztukę Hamptona zresztą nadal thumaczę, ale mam wrażenie, że reaguję na nią jak człowiek i wielbiciel literatury, a nie jak muzyk - dotychczas jeszcze żaden temat nie przyszedł mi do głowy, a to chyba niebezpieczny objaw). (MDS, 359; list z 5 kwietnia 1981)

Wielka szkoda, że opera ta nigdy nie powstała, gdyż wraz z filmem Holland (Hampton napisał przecież na podstawie własnej sztuki scenariusz do Całkowitego zaćmienia!57) stanowiłaby prawdopodobnie - zważywszy na temperament i szczególną, podobną Rimbaudowskiej, autoironię Czajkowskiego (to ktoś taki, kto potrafi o sobie powiedzieć, że grał na koncercie „jak ostryga chora na syfilis"; MDS, 18) - świetny polski duet, pokazujący jedną z najciekawszych przyjaźni niemożliwych poezji nowoczesnej, związku homoerotycznego, który okazał się nadzwyczaj płodny.

57 S. Bobowski, op.cit., s. 241. 
Z drugiej jednak strony to, że opera Czajkowskiego nie powstała, a według tej samej sztuki nakręcono znakomity film, świadczy o dominacji drogi, którą wskazuje kino (Rimbaud odkrywca poezji obiektywnej i montażysta nowoczesnego poematu prozą - miał pecha, że zmarł tuż przed wynalazkiem braci Lumière) nad linią wskazaną przez operę i Verlaine'a („de la musique avant toute chose” - „nade wszystko muzyki!” $\left.{ }^{8}\right)$.

Nawet Verlaine'owsko-Rimbaudowskie „rymy” biograficzne są bardziej filmogenne, są raczej nakładaniem się obrazów niż współbrzmieniem:

Kula [w Brukseli] zraniła Rimbauda w przegub, nie w dłoń. Na ekranie przestrzelona dłoń „rymuje się” zgrabnie z przebitą wcześniej dłonią Verlaine'a. Z kolei ranione dłonie poetów stanowią analogię, już niemal magiczną, z ich chorymi kolanami. Faktycznie - lewe kolano Verlaine'a zaczyna puchnąc i dokuczać poecie w 1885 roku i nie przestanie do końca życia (1896), natomiast Rimbaud cierpi z powodu swego prawego kolana już na początku 1891 roku i w tym samym roku poeta umiera, gdyż to, co nazywał w listach guzem i żylakami, okazało się nieubłaganym, złośliwym rakiem ${ }^{59}$.

Verlaine i Rimbaud - to temat bardzo niemuzyczny. Nie tylko opera, ale i żadne wariacje by go nie uniosły. To po prostu film życia.

\section{KATARZYNA KUCZYŃSKA-KOSCHANY}

\section{The gesture of post-mortem writing and other poetic gestures (Verlaine, Rimbaud)}

The essay undertakes to investigate the phenomenon of erotic friendship as an "intertextual friendship" and, at the same time, "somatic (mis) understanding" (German: Un-beziebung). The following considerations include a discussion on the relationship between Paul Verlaine and Arthur Rimbaud, viewed first of all as bohemian characters of bohemian life and the protagonists of the mitologised homo-erotic relationship. Beside a hermeneutic attempt at describing the intimacy shared by both poets, or stages in the development of their intimate relations (with reference to French literature of the subject and texts that have not yet been translated into Polish), the author writes extensively on the reception of the relationship of the legendary pair of friends-lovers

$5^{8}$ P. Verlaine, Sztuka poetycka, przeł. M. Jastrun, w: Antologia poezji francuskiej, oprac. J. Lisowski, t. 3, Warszawa 2000, s. 677.

59 S. Bobowski, op.cit., s. 249. 
in Poland, examining the poems written by Jarosław Iwaszkiewicz and Stefan Napierski, a number of critical studies of the inter-war period, Agnieszka Holland's film Total eclipse and the most recent poetical texts by Ewa Sonnenberg. The essay is complemented by some considerations on similar cases, analogous to the instance of the relationship between the two French poets: epistolary romance between R.M. Rilke and $M$. Tsvetaeva and, important within the context of the reception of Rimbaud in Poland - love/friendship exhibited in the letters between Andrzej Czajkowski and Anita Janowska.

KATARZYNA KUCZYŃSKA-KoschaNY - dr, adiunkt w Zakładzie Poetyki i Krytyki Literackiej Instytutu Filologii Polskiej UAM. Związana z Pracownią Badań nad Tradycją Europejską Instytutu Filologii Polskiej UAM. Eseistka, prozaik, autorka książek Rilke poetów polskich (2004) oraz Rycerz iŚmierć. O „Elegiach duinejskich” Rainera Marii Rilkego (2010), a także tomu prozy Zielony promień (2006). Współautorka podręcznika Staropolskie korzenie wspótczesności (2004). Członkini Rilke-Gesellschaft. Przygotowuje książkę Nic nie zdarza się na sprawa piękna. Polskie czytania Rimbauda. e-mail: koschany@wp.pl 
